University of Nebraska - Lincoln

DigitalCommons@University of Nebraska - Lincoln

\title{
Endocrine Responses of Fast- and Slow-Growing Families of Channel Catfish
}

\author{
Brian C. Peterson \\ United States Department of Agriculture, bpeterson@ars.usda.gov \\ Brian C. Small \\ United States Department of Agriculture \\ Geoffrey C. Waldbieser \\ United States Department of Agriculture \\ Brian G. Bosworth \\ United States Department of Agriculture
}

Follow this and additional works at: https://digitalcommons.unl.edu/usdaarsfacpub

Part of the Agricultural Science Commons

\footnotetext{
Peterson, Brian C.; Small, Brian C.; Waldbieser, Geoffrey C.; and Bosworth, Brian G., "Endocrine Responses of Fast- and Slow-Growing Families of Channel Catfish" (2008). Publications from USDA-ARS / UNL Faculty. 578.

https://digitalcommons.unl.edu/usdaarsfacpub/578
}

This Article is brought to you for free and open access by the U.S. Department of Agriculture: Agricultural Research Service, Lincoln, Nebraska at DigitalCommons@University of Nebraska - Lincoln. It has been accepted for inclusion in Publications from USDA-ARS / UNL Faculty by an authorized administrator of DigitalCommons@University of Nebraska - Lincoln. 


\title{
Endocrine Responses of Fast- and Slow-Growing Families of Channel Catfish
}

\author{
Brian C. Peterson, * Brian C. Small, Geoffrey C. Waldbieser, and Brian G. Bosworth \\ U.S. Department of Agriculture, Agricultural Research Service, \\ Catfish Genetics Research Unit, Thad Cochran National Warmwater Aquaculture Center, \\ Post Office Box 38, Stoneville, Mississippi 38776, USA
}

\begin{abstract}
Sixty-eight families of USDA303 channel catfish Ictalurus punctatus were evaluated for growth performance for $30 \mathrm{~d}$. The fastest- and slowest-growing catfish families were further evaluated to examine the hypothesis that genes or gene products associated with the growth regulatory and stress axes can be used to describe differences in growth performance. Research examined mRNA levels of genes involved in the growth hormone-insulin-like growth factor (GH-IGF) network in fast- (family A) and slow-growing (family H) USDA303 catfish. Fish $(59.0 \pm 2.4 \mathrm{~g})$ were fed for 7 weeks, weighed, and had tissues for RNA extraction. The remaining fish were subjected to an acute 10-min dewatering stress. Insulin-like growth factor-II mRNA was higher in the muscle of fast-growing fish, while the levels of IGF-I receptor (IGF-IR) and IGF-II receptor (IGF-II) were similar. Muscle IGF-IIR mRNA was two-fold higher than muscle IGF-IR mRNA. There were no differences in liver and muscle IGF-I and GH receptor mRNA or pituitary GH mRNA between the fastand slow-growing fish. Fast-growing fish consumed $135 \%$ more feed than slow-growing fish, though the abundances of ghrelin mRNA in the gut and neuropeptide Y mRNA in the hypothalamus were similar. Cortisol levels were negatively correlated to weight gain. These results suggest that the variation in growth between fast- and slow-growing USDA303 catfish is explained, in part, by the variation in the GH-IGF and stress axes. The relationship between cortisol and weight gain warrants further investigation for possible exploitation in our selective breeding program.
\end{abstract}

The USDA103 research strain of channel catfish Ictalurus punctatus was developed by family selection for improved growth rate. Continued selection within this line is focused on growth, fillet yield, and resistance to Edwardsiella ictaluri, the bacterium that causes enteric septicemia of catfish. The current method of identifying superior broodstock for growth is to conduct growth studies with large numbers of catfish families. This method is expensive and labor intensive owing to the numbers of families that are evaluated each year (approximately 100). The impetus to the current research is the desire to understand the physiological and genetic basis for the variation in growth phenotypes that is observed in our catfish families. We are interested in identifying markers that can be used to identify individuals with superior growth characteristics.

Genetic variation that affects growth will probably be reflected in the growth hormone-insulin-like growth factor (GH-IGF) regulatory axis. Pérez-Sánchez and Le Bail (1999) first suggested the use of the GH-IGF axis as a marker for growth performance in fish. In support of their hypothesis, GH levels were shown to be higher in faster-growing domestic Atlantic salmon

\footnotetext{
* Corresponding author: bpeterson@ars.usda.gov
}

Received March 15, 2007; accepted July 18, 2007 Published online March 27, 2008
Salmo salar than in a wild population (Fleming et al. 2002). Variations in growth performance among broodstock rainbow trout Oncorhynchus mykiss families were explained by variations in the resting levels of GH and IGF-I (Lankford and Weber 2006). In channel catfish, IGF-II mRNA levels were higher in both muscle and liver of faster-growing fish (Peterson et al. 2004b). These results suggest a genetic basis for the variation in the growth performance of the broodstock and families of fish. In addition, genes and gene products related to the GH-IGF axis partially explained differences in superior growth performance. Thus, these molecules could be used as markers for selective breeding.

The neuroendocrine control of GH is multifactorial, multiple stimulatory and inhibitory factors controlling GH secretion (Peter and Chang 1999). Ghrelin and neuropeptide Y (NPY) are two neuropeptides important in the regulation of GH in relation to food intake (Canosa et al., 2007). Two ghrelin genes were recently characterized in channel catfish, the highest abundance being reported in the stomach (Kaiya et al. 2005). The results also showed that ghrelin stimulates GH gene expression and GH release in channel catfish (Kaiya et al. 2005). Neuropeptide $Y$ is a powerful stimulus of eating behavior in species of fish such as goldfish Carassius auratus (Lopez-Patino et al. 1999; Narnaware et al. 2000) and channel catfish (Silverstein and 
Plisetskaya 2000). In channel catfish, NPY is found in the immature ovary, hypothalamus, myelencephalon, telencephalon, and optic tectum of the brain (Leonard et al. 2001). Regulation of gene expression in these tissues has not been examined.

It is clear that the USDA103 line of catfish exhibits superior growth characteristics (Wolters et al. 2000; Jackson et al. 2003; Peterson and Small 2006) compared with other strains of channel catfish. The faster growth of the USDA103 line is often attributed to its ability to consume more feed ( $\mathrm{Li}$ et al. 2001). The stimulus that causes the USDA103 line to consume more feed is unknown but may include ghrelin, NPY, or both.

Cortisol responses may also be associated with growth performance. For example, rainbow trout with a consistently higher plasma cortisol response to stress were significantly larger than fish selected as lowplasma-cortisol responders (Pottinger and Carrick 1999). In two lines of rainbow trout broodstock, Lankford and Weber (2006) demonstrated a positive correlation between cortisol responsiveness and body weight. A clear understanding of the association between cortisol responsiveness and body growth has not been achieved to date. Furthermore, this association has not been examined among channel catfish families.

The present study was conducted to help better understand the mechanisms that regulate growth in channel catfish and test the hypothesis that differences in levels of components of the GH-IGF axis are correlated to differences in growth rates among fastand slow-growing families of catfish. Further, the association between body weight and cortisol response was examined.

\section{Methods}

Catfish families.-The catfish used in this study were derived from the USDA103 line (described by Wolters et al. 2000). This line has been further selected for growth, fillet yield, and resistance to E. ictaluri for an additional two generations to produce the USDA303 line. The USDA303 fish used in the current research were obtained from natural pond spawns and reared in indoor tanks in a common environment at the U.S. Department of Agriculture, Agricultural Research Service, Catfish Genetics Research Unit, in Stoneville, Mississippi. The families used in the present study were selected from 68 full-sib families of the USDA303 strain that had undergone a 30-d growth study; the four fastest-growing and the four slowestgrowing families were selected. The previous 30-d study only had one replicate per family, and the current study was conducted to increase the number of replicates between families.
Prior to randomization into experimental tanks, approximately 50 fish from each of the eight selected families were placed into separate 120-L holding tanks for $1 \mathrm{~d}$. The slower-growing population averaged 51.0 $\pm 5.2 \mathrm{~g}$ (mean $\pm \mathrm{SE}$ ) and the faster-growing population averaged $58.8 \pm 3.4 \mathrm{~g}$. Forty catfish averaging $59.0 \pm 2.4 \mathrm{~g}$ (average of all eight families, total $n=320$ ) were then randomly assigned to four 151-L tanks (10 fish/tank) and allowed to acclimate for $11 \mathrm{~d}$. The fish were fed once per day to apparent satiation and reared in $26.7 \pm 0.3^{\circ} \mathrm{C}$ flow-through well water with a photoperiod of $14 \mathrm{~h}$ light : $10 \mathrm{~h}$ dark. A commercial $36 \%$ crude protein floating catfish feed (Melick Aquafeed, Catawissa, Pennsylvania) was used throughout the study. Water quality $(\mathrm{pH} \sim 8.5$ and dissolved oxygen level $>5.0 \mathrm{mg} / \mathrm{L}$ ) and flow rates were similar between tanks. The fish were maintained for 7 weeks and the amount of feed was recorded weekly. No mortalities were observed throughout the study. Feed conversion ratios (FCRs) were calculated as ingested food $(\mathrm{g}) /$ weight increase $(\mathrm{g})$. Specific growth rates (SGRs) were calculated as $\left[\log _{e}(\mathrm{WT})-\right.$ $\left.\log _{e}(\mathrm{wt})\right] / T \times 100$, where WT and wt are the initial and final weights, respectively, and $T$ is time in days. The studies were conducted in accordance with the principles of and procedures approved by the Institutional Animal Care and Use Committee of the Catfish Genetics Research Unit.

Sample collection and RNA purification.-After the 7-week growth study, fish were anesthetized with $0.1 \mathrm{~g}$ tricaine methanesulfonate (MS-222; Western Chemical, Ferndale, Washington) per L of water and individually weighed and measured. Three fish from each tank (12/family) were euthanized with an overdose of MS-222 $(0.3 \mathrm{~g} / \mathrm{L})$ and their tissues were taken for analysis. A transverse slice of fast muscle (approximately $100 \mathrm{mg}$ ) located beneath the dorsal fin was taken for RNA extraction. Liver, pituitary, hypothalamus, and stomach $(\sim 100 \mathrm{mg})$ were also taken for RNA extraction. Samples were immediately placed in $1 \mathrm{~mL}$ TRI-Reagent (Molecular Research Center, Cincinnati, Ohio) and then flash-frozen in liquid nitrogen. Total RNA was isolated and quantified by measuring the absorbance at $260 \mathrm{~nm}$ using a NanoDrop ND-1000 spectrophotometer (NanoDrop Technologies, Rockland, Delaware), and the integrity of the RNA was verified by visualization of the $18 \mathrm{~S}$ and $28 \mathrm{~S}$ ribosomal bands stained with ethidium bromide after electrophoresis on $2.0 \%$ agarose gels.

Stress challenge.-One week after the eight families of fish were sampled, the remaining fish in each tank (7 fish) were subjected to an acute confinement stressor. The stress was accomplished by total removal of the water from each aquarium. The volume of water was 
TABLE 1.-Nucleotide sequences of the polymerase chain reaction (PCR) primers and probes used to assay gene expression by real-time quantitative PCR for neuropeptide Y (NPY), insulin-like growth factor I receptor (IGF-IR), and insulin-like growth factor II receptor (IGF-IIR).

\begin{tabular}{lllc}
\hline Gene & Primer $^{\mathrm{a}}$ & \multicolumn{1}{c}{ Sequence } & $\begin{array}{c}\text { PCR product } \\
\text { length (base pairs) }\end{array}$ \\
\hline NPY & Sense & CAT CAA CTA ACT ATG CGT CCT CG & 118 \\
& Antisense & CTG GGT TCT CCG GCT TTG T & 118 \\
\multirow{4}{*}{ IGF-IR } & Probe & TCA GCC AGC ACG CAC AAA CAC ACA AC & 148 \\
& Sense & AGT GGT GAA GTG GTC TCC TC & \\
& Antisense & TGT GGC TGA GAT GCG GAT TG & 126 \\
IGF-IIR & Probe & AAC TAC TGC TCG AAA GAA CTG AAG ATC CC & \\
& Sense & CTG CCA CAG AAT TTA TCA GCG & \\
& Antisense & GCA GTG CGC CAT TCA AAC AAG & \\
& Probe & ACT GGC TTC CCC GGA TTC TTG CT & \\
\hline
\end{tabular}

\footnotetext{
${ }^{a}$ The probes for NPY (GenBank accession number AF267164), IGF-IR (EF470421), and IGF-IIR (EF470420) were duallabeled with a reporter dye (FAM; 6-carboxyfluorescein) at the $5^{\prime}$ end and a quencher dye (Black Hole quencher-1) at the $3^{\prime}$ end (Biosearch Technologies, Novato, California).
}

drained in approximately 3 min and the fish exposed to air for $10 \mathrm{~min}$. Four fish per tank were anesthetized with $6 \mathrm{mg}$ metomidate hydrochloride/L and bled from the caudal vasculature into syringes coated with heparin. Metomidate hydrochloride blocks the handling-related release of cortisol into circulation, minimizing endogenous plasma cortisol variability due to sampling (Small 2003). The plasma was separated and frozen at $-20^{\circ} \mathrm{C}$.

Cortisol determination.-Cortisol was measured using a DELFIA time-resolved fluroimmunoassay kit (Perkin-Elmer Life Sciences, Boston, Massachusetts). This kit has been validated for the quantification of plasma cortisol in channel catfish (Small and Davis 2003).

Real-time PCR.-One microgram of total RNA from each tissue was reverse-transcribed using the iScript cDNA Synthesis Kit (BioRad, Hercules, California) according to the protocol provided by the manufacturer. Quantitative real-time polymerase chain reaction (PCR) was performed using the iCycler iQ real-time PCR detection system (BioRad) to quantify IGF-I, IGF-II, alpha tubulin, ghrelin, GH, and growth hormone receptor (GHR) mRNA as previously described (Peterson et al. 2004b; Bilodeau and Waldbieser 2005; Kaiya et al. 2005; Peterson and Small 2005; Small et al. 2006). Primer and probe sequences and GenBank accession numbers for NPY, insulin-like growth factor-I receptor (IGF-IR), and insulin-like growth factor-II receptor (IGF-IIR) are listed in Table 1. The PCR fragments for these three genes were cloned into the pCR4-TOPO vector (Invitrogen, Carlsbad, California) and introduced into One Shot TOP10 Chemically Competent Esherichia coli (Invitrogen) cells, and the identity of the cloned inserts was confirmed by using an automated capillary DNA sequencer (ABI PRISM 3100 Genetic Analyzer; Applied Biosystems, Foster City, California). The DNA concentration of each resulting recombinant plasmid was measured using the NanoDrop ND-1000 spectrophotometer. Each amplification reaction mixture $(12.5 \mu \mathrm{L})$ contained $400 \mathrm{ng}$ of cDNA; $1 \times \mathrm{iQ}$ Supermix (Bio-Rad Laboratories), $2.5 \mu \mathrm{M}$ dual-labeled probe, and $10 \mu \mathrm{M}$ (IGF-IIR) or $20 \mu \mathrm{M}$ (IGF-IR, NPY) of each primer. The real-time PCR protocol for NPY, IGF-IR, and IGF-IIR was $3 \mathrm{~min}$ at $95^{\circ} \mathrm{C}$ followed by 45 cycles of $95^{\circ} \mathrm{C}$ for $15 \mathrm{~s}$ and $60^{\circ} \mathrm{C}$ for $1 \mathrm{~min}$. All amplifications were performed in triplicate. The standard curve showed a linear relationship between cycle threshold values and the logarithm of the input gene copy number. All specific quantities were normalized against the amount of alpha tubulin amplified because there was no significant family effect on the alpha tubulin expression levels.

Statistical analysis.-Statistical analyses were conducted using the mixed procedure of the Statistical Analysis System (SAS version 9.1) followed by a Duncan's multiple-range test. Normalized gene expression data passed Levene's test for homogeneity of variance. Tissue gene expression levels, weight gain, SGR, FCR, food intake, and condition factor $(K$; ratio of body weight to cube of body length) were subjected to one-way analysis of variance (ANOVA) with family as a fixed effect and tank within family as a random effect. Tank served as the experimental unit for each variable measured. Differences among families were considered significantly different at $P<0.05$. A Pearson product-moment correlation coefficient was used to determine the relationship between weight gain and level of cortisol. A critical value table was used to test for significance. 
TABLE 2.-Weight gain, specific growth rate (SGR), food intake per tank, food conversion ratio (FCR), and condition factor $(K)$ of fast- and slow-growing families of USDA303 channel catfish. Means are least-squares means and SEs are the pooled standard errors of the means. See text for variable definitions. Within columns, values with different letters are significantly different $(P<0.05)$.

\begin{tabular}{cccccc}
\hline Family $^{\mathrm{a}}$ & Weight gain $(\mathrm{g})$ & $\mathrm{SGR}$ & Food intake $(\mathrm{g})$ & FCR & $K$ \\
\hline $\mathrm{A}$ & $142.1 \mathrm{z}$ & $2.00 \mathrm{zy}$ & $169.2 \mathrm{z}$ & $1.19 \mathrm{z}$ & $1.01 \mathrm{z}$ \\
$\mathrm{B}$ & $123.1 \mathrm{zy}$ & $2.21 \mathrm{zy}$ & $154.7 \mathrm{zy}$ & $1.26 \mathrm{z}$ & $1.00 \mathrm{zy}$ \\
$\mathrm{C}$ & $114.3 \mathrm{zy}$ & $2.32 \mathrm{zy}$ & $140.3 \mathrm{zyx}$ & $1.23 \mathrm{z}$ & $0.94 \mathrm{zy}$ \\
$\mathrm{D}$ & $113.8 \mathrm{zy}$ & $2.24 \mathrm{z}$ & $121.9 \mathrm{zyx}$ & $1.08 \mathrm{y}$ & $0.94 \mathrm{zyx}$ \\
$\mathrm{E}$ & $98.7 \mathrm{xw}$ & $2.18 \mathrm{zy}$ & $119.8 \mathrm{yxw}$ & $1.21 \mathrm{z}$ & $0.97 \mathrm{zyx}$ \\
$\mathrm{F}$ & $93.9 \mathrm{xw}$ & $1.86 \mathrm{yx}$ & $113.5 \mathrm{xw}$ & $1.21 \mathrm{z}$ & $0.93 \mathrm{xw}$ \\
$\mathrm{G}$ & $78.9 \mathrm{wu}$ & $1.88 \mathrm{yx}$ & $91.3 \mathrm{wu}$ & $1.16 \mathrm{z}$ & $0.88 \mathrm{xy}$ \\
$\mathrm{H}$ & $61.4 \mathrm{u}$ & $1.67 \mathrm{x}$ & $72.1 \mathrm{u}$ & $1.17 \mathrm{z}$ & $0.86 \mathrm{w}$ \\
$\mathrm{SE}$ & 3.8 & 0.05 & 4.6 & 0.01 & 0.11 \\
\hline
\end{tabular}

${ }^{a}$ Families A-D were designated as fast growing and families E-H as slow growing based on a previous 30-d study.

\section{Results}

\section{Growth Performance}

Of the eight families tested, family A gained more weight, consumed more feed, and had a higher $K$ and SGR than family $\mathrm{H}$ (Table 2); the food conversion ratio was similar between the two families. Because family A had the highest growth rate during a previous 30-d growth study as well as the highest SGR in the present 7-week study, it was designated as the "fast"-growing family. Similarly, because family $\mathrm{H}$ had one of the lowest growth rates during a previous 30-d growth study as well as the lowest SGR in the present 7-week study, it was designated as the "slow"-growing family. All gene expression comparisons were made against these two families. These results confirmed genetic differences in fingerling growth among USDA303 channel catfish families.

\section{Abundance of IGF-I, IGF-IR, IGF-II, and IGF-IIR mRNA}

Partial cDNA sequences of the IGF-IR and IGF-IIR genes were identified by sequencing plasmid clones in a library produced from whole-fry cDNA. The similarity of catfish clones to known peptides was determined by means of BlastX similarity searches against the GenBank nonredundant database. Two clones contained partial-length inserts that provided an 828-amino-acid open reading frame closely matching the IGF-Ia receptor of the zebrafish Danio rerio (amino acid identity, $79 \%$; probability of sequence match by chance, $<1 \times 10^{-178}$ ). A third clone provided a 226amino-acid open reading frame most similar to the zebrafish mannose-6-phosphate IGF-II receptor (amino acid identity, $79 \%$; probability of sequence match by chance, $<1 \times 10^{-106}$ ). These sequences also matched the IGF-I and IGF-II receptor sequences, respectively, of other teleosts and mammals at high levels of sequence identity.
The levels of IGF-I mRNA were similar in the muscle and liver of the fast- and slow-growing fish, respectively (Figure 1A, B). The abundance of IGF-II mRNA was greater in the muscle of fast-growing fish than in that of slow-growing fish (Figure 2A, B), while there was no difference in the abundance of IGF-II mRNA in the liver. The levels of IGF-IR and IGF-IIR in the muscle were similar between the two groups of fish (Figures 1C and 2C). However, the abundance of IGF-IIR was 2.5 times higher than that of IGF-IR mRNA in the muscle.

\section{Abundance of GH and GHR, Ghrelin, and NPY $m R N A$}

Growth hormone receptor mRNA in muscle and liver was similar between fast- and slow-growing channel catfish (Figure 3A, B). Pituitary GH mRNA was also similar between fast- and slow-growing fish (Figure 3C). Although the fast-growing fish consumed over twice as much feed as the slow-growing fish, there was no significant difference in the abundance of ghrelin or NPY mRNA (Figure 4).

\section{Stress Challenge}

There was a negative correlation $(-0.4907)$ between weight gain and plasma cortisol level among the four fast-growing and four slow-growing families of channel catfish. Fish that gained more weight during the 7-week growth study tended to have a lower level of cortisol after they were subjected to an acute 10-min confinement stressor.

\section{Discussion}

The objectives of the present study were to compare the components of the GH-IGF regulatory axis between fast-growing and slow-growing channel catfish and to gain a better understanding of the connection between stress responsiveness and growth performance. Toward this goal, we utilized real-time 
Muscle IGF-I mRNA

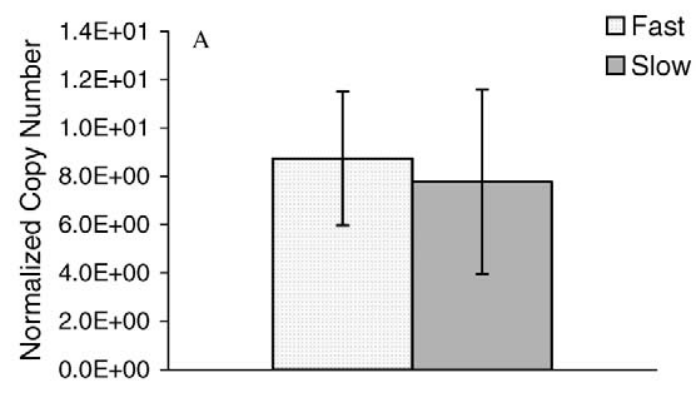

Liver IGF-I mRNA

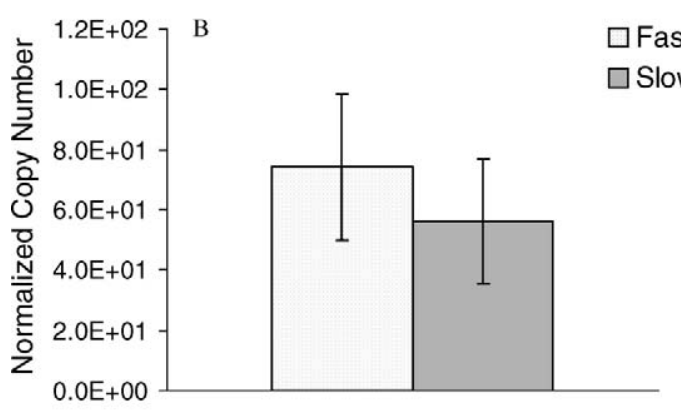

Muscle IGF-IR mRNA

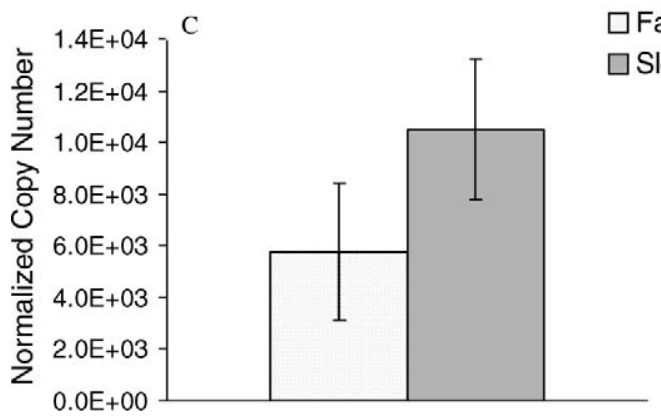

FIGURE 1.-Mean \pm SE (A) muscle IGF-I, (B) liver IGF-I, and (C) muscle IGF-I receptor (IGF-IR) mRNA levels in fastand slow-growing families of channel catfish $(N=4$ fish per family). The IGF-I copy numbers were normalized as ratios of the amount of alpha tubulin. The means were not significantly different $(P>0.05)$.

PCR assays to measure the levels of GH, GHR, IGF-I, IGF-IR, IGF-II, IGF-IIR, ghrelin, and NPY mRNA. The fast- and slow-growing fish used in this study were selected from 68 full-sib families that had previously undergone a 30-d growth study. The results of the prior study were similar to those of the present study. These
Muscle IGF-II mRNA

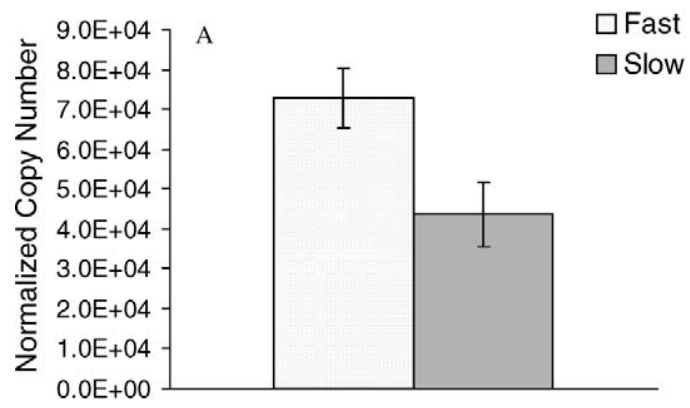

Liver IGF-II mRNA

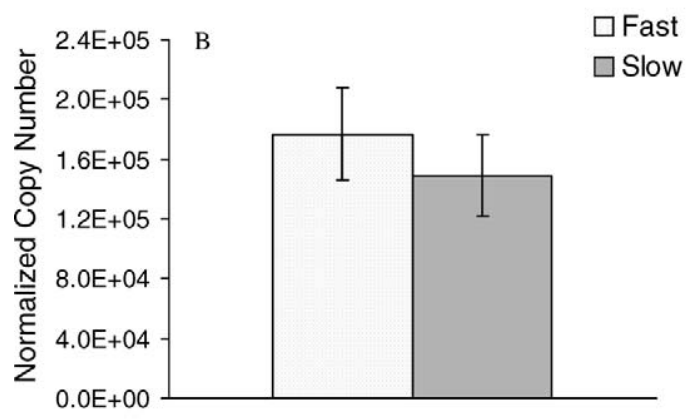

Muscle IGF-IIR mRNA

口Fast

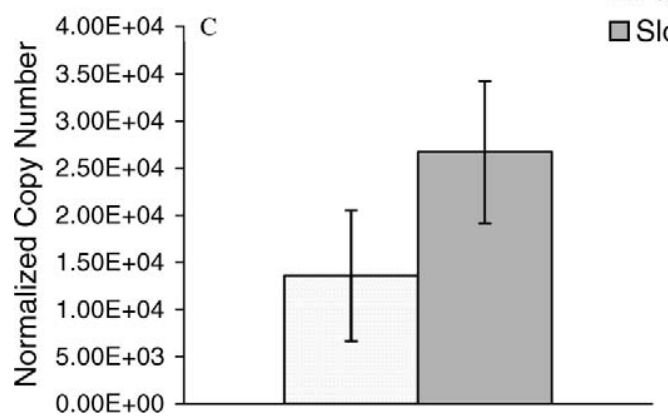

FIGURE 2.-Mean \pm SE (A) muscle IGF-II, (B) liver IGFII, and (C) muscle IGF-II receptor (IGF-IIR) mRNA levels in fast- and slow-growing families of channel catfish $(N=4$ fish per family). The IGF-II copy numbers were normalized as ratios of the amount of alpha tubulin. Significant differences $(P<0.05)$ are denoted by asterisks.

experiments demonstrated genetic growth differences among USDA303 channel catfish families.

The relationship between growth and the GH-IGF axis is complex. Studies in fish have suggested that ideal growth performance is achieved with low plasma $\mathrm{GH}$ in combination with a high concentration of hepatic GHRs and high circulating levels of IGFs 
Muscle GHR mRNA

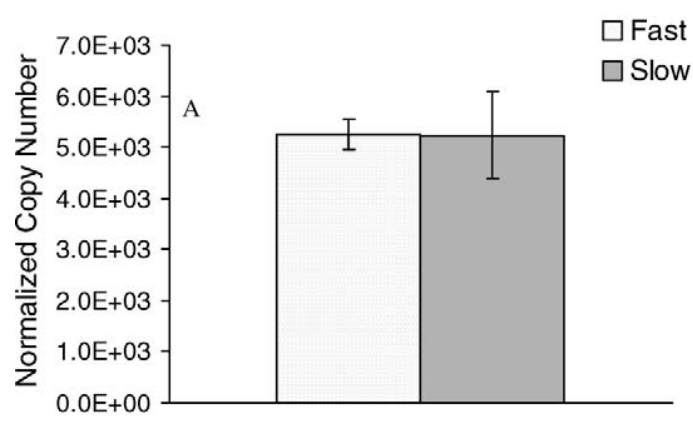

Liver GHR mRNA

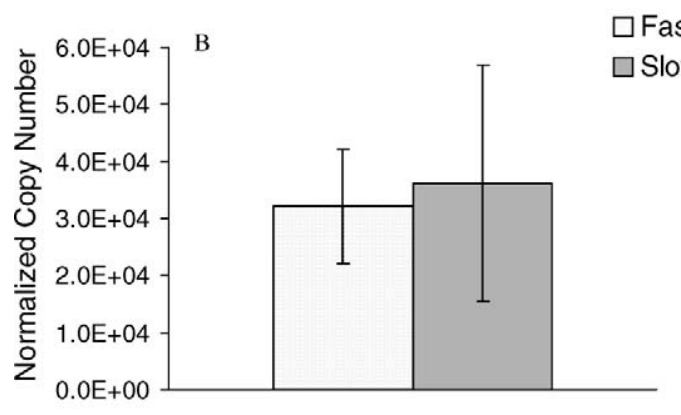

Pituitary GH mRNA

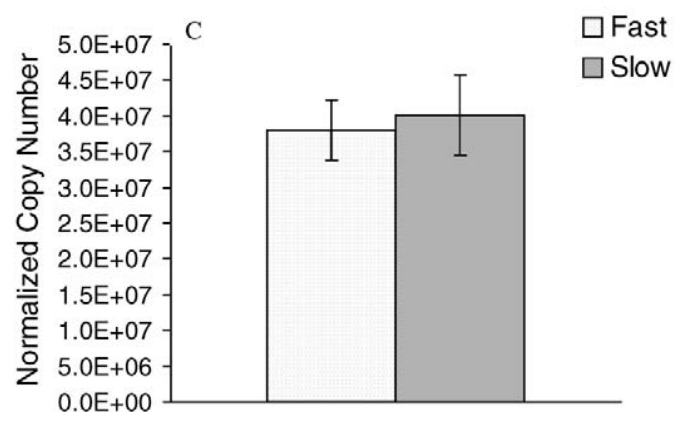

Figure 3.-Mean \pm SE (A) muscle GH receptor (GHR), (B) liver GH receptor, and (C) pituitary GH mRNA levels in fast- and slow-growing families of channel catfish $(N=4$ fish per family). The GH receptor and GH copy numbers were normalized as ratios of the amount of alpha tubulin. The means were not significantly different $(P>0.05)$.

(Pérez-Sánchez and Le Bail 1999). In general, plasma GH levels follow physiological and nutritional status, increased levels being correlated with reduced growth and nutritional status. In support of this hypothesis, Lankford and Weber (2006) reported a negative correlation between body weight and resting plasma $\mathrm{GH}$ in rainbow trout. Conversely, Atlantic salmon parr
Hypothalamus NPY mRNA

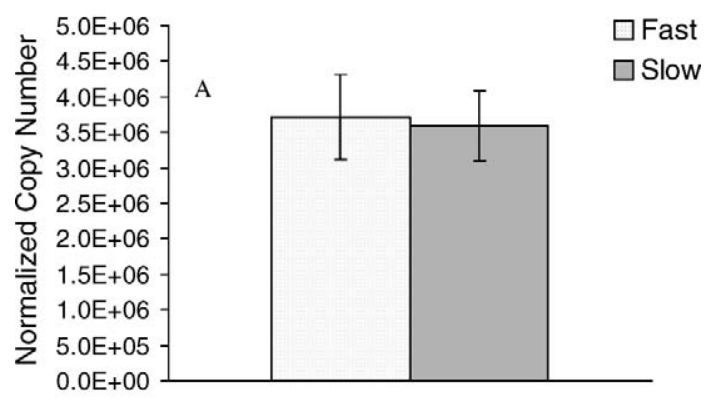

Stomach Ghrelin mRNA

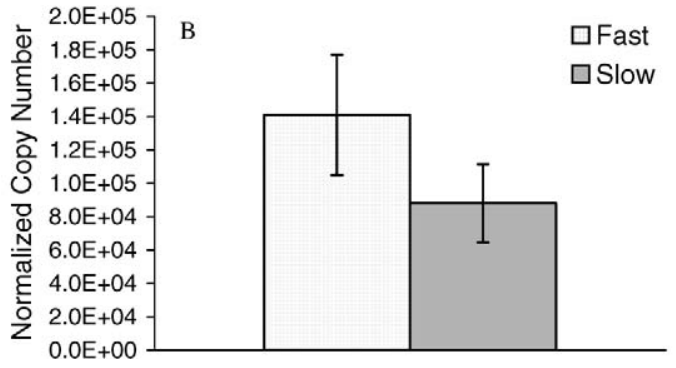

FIGURE 4.-Mean \pm SE (A) hypothalamus neuropeptide Y (NYP) and (B) stomach ghrelin mRNA levels in fast- and slow-growing families of catfish ( $N=4$ fish per family). The NYP and ghrelin copy numbers were normalized as ratios of the amount of alpha tubulin. The means were not significantly different $(P>0.05)$.

exposed to acute stressors had slower growth and higher levels of plasma GH than nonstressed controls (McCormick et al. 1998). Catfish fasted for 4 weeks also had higher levels of pituitary GH mRNA (Small and Peterson 2005). Peterson and Small (2005) fed cortisol to channel catfish and reported a 10-fold reduction in pituitary GH mRNA. The results of the catfish studies suggest that GH may also track the physiological and nutritional status of the fish. In the current study, we did not measure the abundance of pituitary GH mRNA in all eight catfish families to see if there was an association with weight gain. However, there was no difference in the levels of pituitary GH mRNA between fast- and slow-growing fish.

Growth hormone treatment has been found to improve the FCR in catfish studies (Wilson et al. 1988; Peterson et al. 2004a). We found that the FCR was similar between the fast- and slow-growing catfish. Given this, it is not surprising that pituitary GH mRNA was also similar. However, the lack of difference in 
pituitary GH mRNA may simply reflect the fact the both groups of fish were in an anabolic growing state.

We found no statistical difference in levels of GHR mRNA in the liver and muscle of fast- and slowgrowing catfish. The role of GHR in growth is complex and probably involves the coordination of many components of the GH-IGF axis. A recent study reported that GHR mRNA abundance in the liver of cortisol-fed and fasted catfish was significantly reduced, supporting the role of GHR under catabolic conditions (Small et al. 2006). The lack of difference between muscle and liver GHR mRNA between the fast- and slow-growing catfish may also reflect the anabolic status of the fish.

The levels of IGF-I and IGF-II mRNA were measured in both the muscle and liver of experimental fish, while IGF-IR and IGF-IIR mRNAs were quantified in the muscle. In all fish (fast and slow growing), IGF-II mRNA was more abundant in the muscle and liver than IGF-I mRNA and IGF-IIR mRNA levels were two-fold higher than IGF-IR mRNA levels. These results confirmed prior research showing that the levels of IGF-II mRNA levels in muscle and liver were higher than those of IGF-I mRNA (Peterson et al. 2004b). Similarly, the present research confirmed that the levels of IGF-II mRNA are greater in the muscle and liver of fast-growing fish (Peterson et al. 2004b). However, the levels of IGF-II mRNA in the liver were similar between the two phenotypes in the present study. The reason for the disparity between the two studies is not clear, but the results of both studies suggest a role for IGF-II in channel catfish growth.

The physiological role of IGF-II in fish is slowly evolving. In mammals, IGF-II mRNA is detected in fetal tissues but decreases quickly during postnatal development (Daughaday and Rotwein 1989). In contrast, teleostean tissues express substantial amounts of IGF-II later in life (Gabillard et al. 2003; Chauvigné et al. 2003; Radaelli et al. 2003; Vong et al. 2003; Caelers et al. 2004). Growth hormone dependent expression of IGF-II mRNA has been demonstrated in fish (Shamblott et al. 1995; Greene et al. 1999; Vong et al. 2003; Peterson et al. 2005). Using Mozambique tilapia Oreochromis mossambicus as a model, Kajimura et al. (2001) have shown that IGF-II also negatively regulates pituitary $\mathrm{GH}$ expression in vitro. In a recent study, handling and confinement stress resulted in decreases in plasma levels of IGF-II in Atlantic salmon and rainbow trout (Wilkinson et al. 2006). Starvation causes a reduction in the circulating levels of IGF-II (Gentil et al. 1996; Wilkinson et al. 2006). The lack of commercially available channel catfish IGF-II and antibody has hampered our efforts to understand the role of circulating IGF-II under anabolic and catabolic conditions. The production of recombinant catfish IGF-II is currently under way.

The levels of IGF-I mRNA were similar in the muscle and liver of the fast- and slow-growing fish, confirming previous research (Peterson et al. 2004b). The lack of difference in hepatic expression of IGF-I was surprising in both studies, since faster growth was presumably being mediated by IGF-I. However, this does not imply that IGF-I has no function in the growth of channel catfish. The fact that muscle and liver IGF-I mRNA levels were not related to the growth rate of the faster-growing fish only means that muscle and liver IGF-I mRNA cannot explain differences in growth between the two families (Peterson et al. 2004b). It is possible that IGF-I produced by other tissues plays a significant role in the growth of channel catfish. The IGF-I gene is expressed in several teleostean tissues, including the brain, heart, gill, intestine, kidney, spleen, and testes (Vong et al. 2003; Biga et al. 2004; Caelers et al. 2004; Clay et al. 2005). Perhaps an autocrine/ paracrine role for IGF-I is important in catfish and other species of fish. In mice that have had the IGF-I gene deleted in the liver, liver IGF-I was not essential for normal growth and development (Yakar et al. 1999; Sjogren et al. 1999). These studies provide evidence that autocrine/paracrine IGF-I can support normal postnatal growth and development.

The abundance of muscle IGF-IR mRNA was not different in fast- and slow-growing channel catfish. Similarly, in chickens selected for fast and slow growth, IGF-IR mRNA were similar in the brain, heart, muscle, and liver (Armstrong and Hogg 1994). In rainbow trout, a significant decrease in IGF-IR (types a and b) mRNA abundance was found in the gill of a rapidly growing juvenile rainbow trout relative to that in slower-growing adults (Greene and Chen 1999). In the same study, significant increases were found in the heart for IGF-IRa and the heart, kidney, pyloric caeca, pancreas, adipose, and spleen for IGF-IRb for the faster-growing trout (Greene and Chen 1999). The role of IGF-IR in the growth of channel catfish is currently not known.

The IGF-II receptor has been identified in embryos of the brown trout Salmo trutta (Mendez et al. 2001). In mammals, the IGF-II cation-independent mannose6-phosphate (IGF-II/Man-6-P) receptor is a monomeric receptor that binds to mannose-6-phosphate residues on lysosomal enzymes (Jones and Clemmons 1995). The IGF-II/Man-6-P receptor is thought to function primarily as a degradative pathway to remove IGF-II from the extracellular environment (Jones and Clemmons 1995). The physiological role of the IGF-II/Man-6-P receptor in fish in currently not known. Insulin-like growth 
factor-II receptor mRNA was approximately two-fold higher than IGF-IR mRNA in the muscle in the present study. This study is the first to compare IGF-IR abundance with IGF-IIR abundance in any fish species. The higher levels of IGF-IIR and the high levels of IGF-II mRNA in the muscle suggest a role for IGF-II in muscle growth in channel catfish. An IGF-II mutation was identified as a quantitative trait locus affecting postnatal muscle growth in swine (Van Laere et al. 2003), and allelic polymorphism at the IGF-II locus may prove useful in selecting pigs for faster growth. As such, polymorphism typing of IGF-II in channel catfish merits investigation.

The regulation of food intake in fish is achieved via a complex hypothalamic neural network that integrates multiple stimulatory and inhibitory neuroendocrine signals (Lin et al. 2000). Two stimulatory peptides in fish include ghrelin and NPY. The physiological functions of ghrelin in fish are the regulation of pituitary GH, regulation of food intake, and control of drinking behavior (Unniappan and Peter 2005). In channel catfish, ghrelin has also been shown to stimulate GH gene expression and GH release (Kaiya et al. 2005). Neuropeptide $Y$ is a highly conserved peptide that has been shown to be a powerful stimulator of food intake in goldfish (Lopez-Patino et al. 1999; Narnaware et al. 2000) and channel catfish (Silverstein and Plisetskaya 2000). In the current study, it was hypothesized that the faster-growing fish would consume more feed. As expected, the fast-growing fish consumed more than twice as much feed as the slowgrowing fish. However, there was no significant difference in the abundance of ghrelin or NPY mRNA between these two phenotypes.

Time course changes in the levels of NPY and ghrelin relative to pre- and postfeeding in channel catfish are not known. In the current study, tissue samples were taken during their normal scheduled feeding period, and tissue sampling continued for approximately $1 \mathrm{~h}$. In goldfish and Atlantic cod Gadus morhua, NYP mRNA expression in the brain increases in anticipation of a meal (Narnaware et al. 2000; Kehoe and Volkoff 2007). Although NYP has been shown to a regulator of appetite in catfish (Silverstein and Plisetskaya 2000), it does not appear that NPY mRNA levels are a good modulator of differences in appetite.

Time course changes in ghrelin mRNA expression appear to be species specific. For example, ghrelin expression in the stomach increased after $35 \mathrm{~d}$ of fasting in sea bass Dicentrarchus labrax (Terova et al., in press) and in goldfish after $7 \mathrm{~d}$ (Unniappan et al. 2004), while in Nile tilapia Oreochromis niloticus, ghrelin levels did not change even after $7 \mathrm{~d}$ of fasting (Parhar et al. 2003). Ghrelin mRNA levels in the current study were higher in the faster-growing fish $(P=0.09)$. However, the observed higher levels of ghrelin mRNA in fast-growing fish may have little biological significance given the number of fish that were sampled from both phenotypes (12 from each group). As with NPY mRNA, ghrelin mRNA levels may not be a good modulator of differences in appetite.

Future studies should look at plasma peptide levels of ghrelin and NPY as well as other orexigenic neuropeptides such as cholecystokinin, peptide YY, pancreatic polypeptide, and peptide Y. It is currently not known what regulates the observed higher feed intake among some channel catfish families. An understanding of the neuropeptide(s) involved in regulating appetite in catfish could lead to methods of identifying fish with a higher propensity to consume more feed and thus to have higher growth.

There was a negative correlation between weight gain and plasma cortisol level among the four fastgrowing and four slow-growing families of channel catfish. The results of this study suggest that fish that gained more weight during the study had lower levels of cortisol after they were subjected to an acute 10-min confinement stressor. Associations between cortisol response to a confinement stressor and growth performance have been reported in other species, but they have not been consistent. In a study with rainbow trout broodstock, Lankford and Weber (2006) found a positive correlation between body weight and cortisol response. However, that relationship disappeared when growth performance was quantified by the thermal growth coefficient. Pottinger and Carrick (1999) also found a positive association between cortisol responsiveness and body size in female rainbow trout. Among the progeny of these fish, those responding with low concentrations of cortisol grew faster than the others, but only when the two groups of fish were cocultured (Pottinger and Carrick 2001). In another study, lowcortisol-responding rainbow trout had higher specific growth rates at early life stages than high-cortisolresponding trout (Fevolden et al. 2002). However, the progeny groups in that study were hatched 1 month apart, which makes it difficult to compare specific growth rates. A clear understanding of the relationship between cortisol and growth rate has not evolved. It is likely that there are differences between species and strains and that the elucidation of the relationship between cortisol and growth will require characterization of hormones in addition to cortisol (Lankford and Weber 2006). The significant correlation between stress responsiveness and weight gain should be further investigated for possible exploitation in our selective breeding program.

In conclusion, we utilized quantitative real-time PCR 
assays to measure eight genes in fast- and slowgrowing USDA303 families of channel catfish to test the hypothesis that genes or gene products associated with the growth regulatory and stress axes can be used to describe differences in growth performance. We found that IGF-II mRNA levels in muscle were higher in fast-growing fish. We showed (for the first time in any fish species) that IGF-IIR mRNA levels were twice as high as those of IGF-IR mRNA in muscle. We also demonstrated a negative correlation between weight gain and cortisol. These results suggest that the variation in growth among families of USDA303 catfish is explained, in part, by variation in the $\mathrm{GH}-$ IGF and stress axes. The expression of the gene for IGF-II may reflect differences in muscle growth. The relationship between stress responsiveness and weight gain warrants further investigation.

\section{Acknowledgments}

The authors thank Monica Loden and Jimmy Warren of the USDA-ARS Catfish Genetics Research Unit for their efforts in maintaining the fish, collecting samples, and performing the assays. The authors also thank Chris Murdock for help with the sample collection. Mention of trade names or commercial products is solely for the purpose of providing specific information and does not imply recommendation or endorsement by the U.S. Department of Agriculture.

\section{References}

Armstrong, D. G., and C. O. Hogg. 1994. Type-I insulin-like growth factor receptor gene expression in the chick: developmental changes and the effects of selection for increased growth on the amount of receptor mRNA. Journal of Molecular Endocrinology 12:3-12.

Biga, P. R., G. T. Schelling, R. W. Hardy, K. D. Cain, K. Overturf, and T. L. Ott. 2004. The effects of recombinant bovine somatotropin (rbST) on tissue IGF-I, IGF-I receptor, and $\mathrm{GH}$ mRNA levels in rainbow trout, Oncorhynchus mykiss. General and Comparative Endocrinology 135:324-333.

Bilodeau, L., and G. C. Waldbieser. 2005. Activation of TLR3 and TLR5 in channel catfish exposed to virulent Edwardsiella ictaluri. Developmental and Comparative Immunology 29:713-721.

Caelers, A., G. Berishvili, M. L. Meli, E. Eppler, and M. Reinecke. 2004. Establishment of a real time RT-PCR for the determination of absolute amounts of IGF-I and IGFII gene expression in liver and extrahepatic sites of the tilapia. General and Comparative Endocrinology 137:196-204.

Canosa, L. F., J. P. Chang, and R. E. Peter. 2007. Neuroendocrine control of growth hormone in fish. General and Comparative Endocrinology 151:1-26.

Chauvigné, F., J. C. Gabillard, C. Weil, and P. Y. Resca. 2003. Effect of refeeding on IGFI, IGFII, IGF receptors, FGF2, FGF6, and myostatin mRNA expression in rainbow trout myotomal muscle. General and Comparative Endocrinology 132:209-215.

Clay, L. A., S. Y. Wang, W. R. Wolters, B. C. Peterson, and G. C. Waldbieser. 2005. Molecular characterization of the insulin-like growth factor-I (IGF-I) gene in channel catfish (Ictalurus punctatus). Biochimica et Biophysica Acta 1731:139-148.

Daughaday, W. H., and P. Rotwein. 1989. Insulin-like growth factors I and II: peptide, messenger ribonucleic acid and gene structures, serum, and tissue concentrations. Endocrine Reviews 10:68-91.

Fevolden, S. E., K. H. Roed, and K. T. Fjalestad. 2002. Selection response of cortisol and lysozyme in rainbow trout and correlation to growth. Aquaculture 205:61-75.

Fleming, I. A., T. Agustsson, B. Finstad, J. I. Johnsson, and B. T. Björnsson. 2002. Effects of domestication of growth physiology and endocrinology of Atlantic salmon (Salmo salar). Canadian Journal of Fisheries and Aquatic Sciences 59:1323-1330.

Gabillard, J.-C., C. Weil, P.-Y. Rescan, I. Navarro, J. Gutierrez, and P.-Y. Le Bail. 2003. Effects of environmental temperature on IGF1, IGF2, and IGF type I receptor expression in rainbow trout (Oncorhynchus mykiss). General and Comparative Endocrinology 133:233-242.

Gentil, V., P. Martin, J. Smal, and P.-Y. LeBail. 1996. Production of recombinant insulin-like growth factor-II in the development of a radioimmunoassay in rainbow trout (Oncorhynchus mykiss). General and Comparative Endocrinology 104:156-167.

Greene, M. W., and T. T. Chen. 1999. Characterization of teleost insulin receptor family members II: developmental expression of insulin-like growth factor type I receptor messenger RNAs in rainbow trout. General and Comparative Endocrinology 115:270-281.

Greene, M. W., M. J. Shamblott, and T. T. Chen. 1999. Presence of GH-dependent IGF- II mRNA in the diffuse pancreatic tissue of a teleost. Comparative Biochemistry and Physiology 122B:287-292.

Jackson, S. L., E. H. Robinson, M. H. Li, W. R. Wolters, and D. A. McKee. 2003. Restricted and satiated feeding of two genetically isolated strains of juvenile channel catfish Ictalurus punctatus reared on $28 \%$ and $32 \%$ protein diets. Journal of the World Aquaculture Society 34:478-486.

Jones, J. I., and D. R. Clemmons. 1995. Insulin-like growth factors and their binding proteins: biological actions. Endocrine Reviews 16:3-34.

Kaiya, H., B. C. Small, A. L. Bilodeau, B. S. Shepherd, M. Kojima, H. Hosoda, and K. Kangawa. 2005. Purification, cDNA cloning, and characterization of ghrelin in channel catfish, Ictalurus punctatus. General and Comparative Endocrinology 143:201-210.

Kajimura, S., K. Uchida, T. Yada, T. Hirano, K. Aida, and E. G. Grau. 2001. Effects of insulin-like growth factors (IGF-I and IGF-II) on growth hormone and prolactin release and gene expression in euryhaline tilapia, Oreochromis mossambicus. General and Comparative Endocrinology 127:223-231.

Kehoe, A. S., and H. Volkoff. 2007. Cloning and characterization of neuropeptide Y (NPY) and cocaine and amphetamine regulated transcript (CART) in Atlantic 
cod (Gadus morhua). Comparative Biochemistry and Physiology 146A:451-461.

Lankford, S. E., and G. M. Weber. 2006. Associations between plasma growth hormone, insulin-like growth factor-I, and cortisol with stress responsiveness and growth performance in a selective breeding program for rainbow trout. North American Journal of Aquaculture 68:151-159.

Leonard, J. B. K., G. C. Waldbieser, and J. T. Silverstein. 2001. Neuropeptide Y sequence and RNA distribution in channel catfish (Ictaluris punctatus) 3:111-118.

Li, M., B. B. Manning, E. H. Robinson, B. G. Bosworth, and W. R. Wolters. 2001. Comparison of growth, processing yield, and body composition of USDA103 and Mississippi "normal" strains of channel catfish fed diets containing three concentrations of protein. Journal of the World Aquaculture Society 32:402-408.

Lin, X., H. Volkoff, Y. Narnaware, N. J. Bernier, P. Peyon, and R. E. Peter. 2000. Brain regulation of feeding behavior and food intake in fish. Comparative Biochemistry and Physiology 126A:415-434.

Lopez-Patino, M. A., A. I. Guijarro, E. Isorna, M. J. Delgado, M. Alonso-Bedate, and N. de Pedro. 1999. Neuropeptide $\mathrm{Y}$ has a stimulatory action on feeding behavior in goldfish (Carassius auratus). European Journal of Pharmacology 377:147-153.

McCormick, S. D., J. M. Shrimpton, J. B. Carey, M. F. O'Dea, K. E. Sloan, S. Moriyama, and B. T. Björnsson. 1998. Repeated acute stress reduces growth rate of Atlantic salmon parr and alters plasma levels of growth hormone, insulin-like growth factor I, and cortisol. Aquaculture 168:221-235.

Mendez, E., J. V. Planas, J. Castillo, I. Navarro, and J. Gutierrez. 2001. Identification of a type II insulin-like growth factor receptor in fish embryos. Endocrinology 142:1090-1097.

Narnaware, Y. K., P. P. Peyon, X. Lin, and R. E. Peter. 2000. Regulation of food intake by neuropeptide $\mathrm{Y}$ in goldfish. American Journal of Physiology 279:R1025-R1034.

Parhar, I. S., H. Sato, and Y. Sakuma. 2003. Ghrelin gene in cichlid fish is modulated by sex and development. Biochemical and Biophysical Research Communications 305:169-175.

Pérez-Sánchez, J., and P.-Y. Le Bail. 1999. Growth hormone axis as marker of nutritional status and growth performance in fish. Aquaculture 177:117-128.

Peter, R. E., and J. P. Chang. 1999. Brain regulation of growth hormone secretion and food intake in fish. Pages 55-67 in P. D. Prasada Rao and R. E. Peter, editors. Neural regulation in the vertebrate endocrine system. Kluwer Academic/Plenum Publishers, New York.

Peterson, B. C., and B. C. Small. 2005. Effects of exogenous cortisol on the GH/IGF-I/IGFBPs in channel catfish. Domestic Animal Endocrinology 28:391-404.

Peterson, B. C., and B. C. Small. 2006. Effect of feeding frequency on food consumption, growth, and feed efficiency in aquarium-reared Norris and NWAC103 channel catfish (Ictalurus punctatus). Journal of the World Aquaculture Society 37:490-495.

Peterson, B. C., B. C. Small, and B. G. Bosworth. 2004a. Effects of bovine growth hormone (Posilac ${ }^{\circledR}$ ) on growth performance, body composition, and IGFBPs in two strains of channel catfish. Aquaculture 232:651-663.

Peterson, B. C., G. C. Waldbieser, and A. L. Bilodeau. 2004b. IGF-I and IGF-II mRNA expression in slow- and fastgrowing families of USDA103 channel catfish (Ictalurus punctatus). Comparative Biochemistry and Physiology 139A:317-323.

Peterson, B. C., G. C. Waldbieser, and A. L. Bilodeau. 2005. Effects of recombinant bovine somatotropin on growth and abundance of mRNA for IGF-I and IGF-II in channel catfish (Ictalurus punctatus). Journal of Animal Science 83:816-824.

Pottinger, T. G., and T. R. Carrick. 1999. A comparison of plasma glucose and plasma cortisol as selection markers for high and low stress responsiveness in female rainbow trout. Aquaculture 175:351-363.

Pottinger, T. G., and T. R. Carrick. 2001. Stress responsiveness affects dominant--subordinate relationships in rainbow trout. Hormones and Behavior 40:419-427.

Radaelli, G., M. Patruno, L. Maccatrozzo, and B. Funkenstein. 2003. Expression and cellular localization of insulin-like growth factor-II protein and mRNA in Sparus aurata during development. Journal of Endocrinology 178:285299.

Shamblott, M. J., C. M. Cheng, D. Bolt, and T. T. Chen. 1995. Appearance of insulin- like growth factor mRNA in the liver and pyloric ceca of a teleost in response to exogenous growth hormone. Proceedings of the National Academy of Sciences of the USA 92:6943-6946.

Silverstein, J. T., and E. M. Plisetskaya. 2000. The effects of NYP and insulin on food intake regulation in fish. American Zoologist 40:296-308.

Sjogren, K., J. L. Liu, K. Blad, S. Skrtic, O. Vidal, V. Wallenius, D. LeRoith, J. Tornell, O. G. Isaksson, J. O. Jansson, and C. Ohlsson. 1999. Liver-derived insulin-like growth factor I (IGF-I) is the principal source of IGF-I in blood but is not required for postnatal body growth in mice. Proceedings of the National Academy of Sciences of the USA 96:7088-7092.

Small, B. C. 2003. Anesthetic efficacy of metomidate and comparison of plasma cortisol responses to tricaine methanesulfonate, quinaldine, and clove oil anesthetized channel catfish Ictalurus punctatus. Aquaculture 218:177-185.

Small, B. C., and K. B. Davis. 2003. Validation of a timeresolved fluroimmunoassay for measuring plasma cortisol in channel catfish Ictalurus punctatus. Journal of the World Aquaculture Society 33:184-187.

Small, B. C., and B. C. Peterson. 2005. Establishment of a time-resolved fluoroimmunoassay for measuring plasma insulin-like growth factor I (IGF-I) in fish: effect of fasting on plasma concentrations and tissue mRNA expression of IGF-I and growth hormone $(\mathrm{GH})$ in channel catfish (Ictalurus punctatus). Domestic Animal Endocrinology 28:202-215.

Small, B. C., G. C. Waldbieser, C. A. Murdock, and B. C. Peterson. 2006. Reduction in channel catfish hepatic growth hormone receptor expression in response to food deprivation and exogenous cortisol. Domestic Animal Endocrinology 31:340-256.

Terova, G., S. Rimoldi, G. Bernardini, R. Gornati, and M. Saroglia. In press. Sea bass ghrelin: molecular cloning 
and mRNA quantification during fasting and refeeding. General and Comparative Endocrinology.

Unniappan, S., L. F. Canosa, and R. E. Peter. 2004. Orexigenic actions of ghrelin in goldfish: feedinginduced changes in brain and gut mRNA expression and serum levels and responses to central and peripheral injections. Neuroendocrinology 79:100-108.

Unniappan, S., and R. E. Peter. 2005. Structure, distribution, and physiological functions of ghrelin in fish. Comparative Biochemistry and Physiology 140A:396-408.

Van Laere, A.-S., M. Nguyen, M. Braunschweig, C. Nezer, C. Collette, L. Moreau, A. L. Archibald, C. S. Halley, N. Buys, M. Tally, G. Andersson, M. Georges, and L. Andersson. 2003. A regulatory mutation in IGF2 causes a major QTL effect on muscle growth in the pig. Nature (London) 425:832-836.

Vong, Q. P., K. M. Chan, and C. H. K. Cheng. 2003. Quantification of common carp (Cyprinus carpio) IGF-I and IGF-II mRNA by real-time PCR: differential regulation of expression by GH. Journal of Endocrinology 178:513-521.

Wilkinson, R. J., M. Porter, H. Woolcott, R. Longland, and
J. F. Carragher. 2006. Effects of aquaculture-related stressors and nutritional restriction on circulating growth factors (GH, IGF-I, and IGF-II) in Atlantic salmon and rainbow trout. Comparative Biochemistry and Physiology $145 \mathrm{~A}: 214-224$.

Wilson, R. P., W. E. Poe, T. G. Nemetz, and J. R. MacMillian. 1988. Effect of recombinant bovine growth hormone administration on growth and body composition of channel catfish. Aquaculture 73:229-236.

Wolters, W. R., G. C. Waldbieser, B. G. Bosworth, J. T. Silverstein, E. H. Robinson, M. Li, D. J. Wise, D. Freeman, P. Klesius, and K. B. Davis. 2000. Notice of joint release of catfish line USDA103, which has improved growth performance. U.S. Department of Agriculture, Agricultural Research Service, Washington, D.C., and Mississippi Agricultural and Forestry Experiment Station, Mississippi State.

Yakar, S., J. L. Liu, B. Stannard, A. Butler, D. Accili, B. Sauer, and D. LeRoith. 1999. Normal growth and development in the absence of hepatic insulin-like growth factor I. Proceedings of the National Academy of Sciences of the USA 96:7324-7329. 